(C) Group of authors, 2019

UDC 616.314-089.28/29

DOI - https://doi.org/10.14300/mnnc.2019.14128

ISSN - 2073-8137

\title{
BIORESORBABLE MEMBRANES BASED ON POLYVINYL ALCOHOL AND FULLERENE
}

\author{
Grebnev G. A. 1, Ivanov A. S. ${ }^{1}$, Kabankov A. V. ${ }^{2}$, \\ Garunov M. M. ${ }^{3}$, Rumakin V. P. 1, Borodulina I. I. ${ }^{1}$
}

${ }^{1}$ S. M. Kirov Military Medical Academy, Saint-Petersburg, Russian Federation
2 LLC Smart Dentistry, Saint-Petersburg, Russian Federation
3 LLC NPO Innotech, Saint-Petersburg, Russian Federation

\section{ОСОБЕННОСТИ БИОРЕЗОРБЦИИ МЕМБРАН ААЯ НАПРАВАЕННОЙ РЕГЕНЕРАЦИИ КОСТНОЙ ТКАНИ НА ОСНОВЕ КОМПОЗИЦИИ ПОАИВИНИАОВЫХ СПИРТОВ С АОБАВАЕНИЕМ ФУАМЕРЕНОВ $C_{60}$ В ЭКСПЕРИМЕНТЕ}

\author{
Г. А. Гребнев ${ }^{1}$, А. С. Иванов ${ }^{1}$, А. В. Кабаньков ${ }^{2}$, \\ М. М. Гарунов ${ }^{3}$, В. П. Румакин ${ }^{1}$, И. И. Бородулина ${ }^{1}$
${ }^{1}$ Военно-медицинская академия им. С. М. Кирова, Санкт-Петербург, Российская ФеАерация
2 ООО «Умная стоматология», Санкт-Петербург, Российская Фелерация
3 ООО «НПО Иннотех॥, Санкт-Петербург, Российская ФеАерация

In this study, resorbable membranes based on polyvinyl alcohols with varying degrees of hydrolysis and fullerene $\left(\mathrm{C}_{60}\right)$ were implanted under the femoral muscles of 73 outbred white mice with the aim of targeted bone tissue regeneration. The results of morphological studies showed that the final resorption of the membranes was achieved within 90 days. In the control group that was implanted with membranes based on polyvinyl alcohols without $\mathrm{C}_{60}$, the membranes became encapsulated and did not undergo bioresorption within 90 days.

Keywords: tissue regeneration, resorbable membrane, fullerene, morphological study

В эксперименте 73 беспородным белым мышам под бедренную мышцу, для направленной регенерации костной ткани, имплантировалась резорбируемая мембрана, изготовленная на основе композиции поливиниловых спиртов с добавлением фуллеренов $\mathrm{C}_{60}$. По данным морфологических исследований, полная её резорбция происходила к 90 суткам. В контрольной группе мембрана на основе «классического» поливинилового спирта в те же сроки осумковывалась, не подвергаясь биорезорбции.

Ключевые слова: направленная регенерация костной ткани, резорбируемые мембраны, фуллерены, морфологическое исследование

For citation: Grebnev G. A., Ivanov A. S., Kabankov A. V., Garunov M. M., Rumakin V. P., Borodulina I. I. BIORESORBABLE MEMBRANES BASED ON POLYVINYLALCOHOLAND FULLERENE. Medical News of North Caucasus. 2019;14(3):520523. DOI - https://doi.org/10.14300/mnnc.2019.14128

Для цитирования: Гребнев Г. А., Иванов А. С., Кабаньков А. В., Гарунов М. М., Румакин В. П., Бородулина И. И. ОСОБЕННОСТИ БИОРЕЗОРБЦИИ МЕМБРАН ДЛЯ НАПРАВЛЕННОЙ РЕГЕНЕРАЦИИ КОСТНОЙ ТКАНИ НА ОСНОВЕ КОМПОЗИЦИИ ПОЛИВИНИЛОВЫХ СПИРТОВ С ДОБАВЛЕНИЕМ ФУЛЛЕРЕНОВ С 60 В ЭКСПЕРИМЕНТЕ. МЕДИЦИНСКИЙ вестник Северного Кавказа. 2019;14(3):520-523. DOI - https://doi.org/10.14300/mnnc.2019.14128

PVA - polyvinyl alcohols with varying degrees of hydrolysis

PVAF - polyvinyl alcohols with varying degrees of hydrolysis and added fullerene

$\mathrm{T}$ argeted bone tissue regeneration in dental and maxillofacial surgery and traumatology increasingly uses materials that provide the barrier function of membranes to separate highly differentiated bone tissue from poorly differentiated connective tissue to inhibit rapid growth $[1,2,3$, 4]. For almost a hundred years, materials based on polyvinyl alcohols have been successfully used in medicine as bioprostheses, often as substitutes for large vessels, as well as boat membranes with high chemical resistance and wear resistance $[5,6]$. The introduction of nanoparticles such as fullerene $\left(C_{60}\right)$ into polyvinyl alcohols with varying degrees of hydrolysis can provide membranes capable of 
dissolving at the temperature of the human body. Such membranes can possess the ability to optimize wound healing processes $[7,8]$.

The purpose of the work is to experimentally evaluate the bioresorption of membranes based on polyvinyl alcohols with varying degrees of hydrolysis and $\mathrm{C}_{60}$ for the directed regeneration of bone tissue.

Material and Methods. The experiment was carried out using outbred white mice of both sexes under standard vivarium conditions in accordance with GOST ISO 10993-6-2011 «Medical devices. Assessment of the biological effects of medical devices. Part 6. Local studies after implantation».

The biodegradation of membranes composed of polyvinyl alcohols with varying degrees of hydrolysis and $\mathrm{C}_{60}$ (hereafter abbreviated as PVAF membranes) was studied by implanting PVAF membranes with a size of $1 \times 1 \mathrm{~cm}$ freely under the right femoral muscle of 73 mice (Group A).

The control experiment used a membrane composed of polyvinyl alcohols of varying degrees of hydrolysis (hereafter abbreviated as PVA) without $\mathrm{C}_{60}$. PVA membranes with a size of $1 \times 1 \mathrm{~cm}$ were introduced under the left femoral muscles of the mice in Group A (Subgroup $A$ b). Mice were withdrawn from the experiments on day 14,28 , and 42 ( 21 animals each time).

To study the long-term results of membrane resorption (Group B), cuts with a length of $15 \mathrm{~mm}$ and width of $2 \mathrm{~mm}$ were incised on the right and left femurs of ten animals, which were withdrawn from the experiment at 90 days. A PVAF membrane (Subgroup B a) was placed in the right thigh on the bone defect. As a control, a PVA membrane was placed on the bone defect in the left thigh (Subgroup $\mathrm{B} \mathrm{b})$. After these experiments, a single fragment of the femoral muscle with a portion of the bone was biopsied.

After fixation of the biopsy specimen in a $10 \%$ solution of neutral formalin, traditional wiring and pouring into paraffin, sections with a thickness of $8 \mu \mathrm{m}$ were prepared from it. The preparations were stained with hematoxylineosin and picrofuxin according to van Gieson. The bone was fixed with a $10 \%$ neutral formalin solution for $24 \mathrm{~h}$, decalcified in a saturated Trilon B solution, replaced in $10 \%$ neutral formalin, dehydrated in ascending ethanol using a Microm STP-120 histological material posting unit (Micron Technology, USA), and then poured into paraffin using a Leica filling machine (Leica, Germany). Sections with a thickness of $5 \mu \mathrm{m}$ were obtained using a Leica sled microtome (Leica Microsystems, Germany) and stained with hematoxylin-eosin (Biovitrum, Russia) using a Raffaello stain (Diapath, S.p.A., Italy).

Visualization and optical images of microscale objects was carried out with the hardware-software complex VideoTesT-Morphology (Russia). Microscopic examination was carried out using a light microscope (MIKMED-2, Russia) at magnifications of $40 x, 100 x$, 200x, and 400x.

Biodegradation was evaluated by the severity of the cellular reaction, the volume and maturity of granulations formed around the implant, and the degree of decomposition of the PVAF and PVA membranes. The histological state of each membrane was determined on the following three-point scale. One point: the membrane is present unchanged on the histological preparation and retains its integrity; two points: the membrane is partially absent, its integrity is disrupted, and it is fragmented; three points: only traces of the membrane were detected. The AtteStat version 13.1 program was used for mathematical and statistical evaluation of the obtained results.

Results and Discussion. In the morphological study of the muscle tissue in Group A (free implanted
PVAF membranes), small membrane fragments in granulations, clumps of foreign light-refracting material in the cytoplasm of macrophages and giant multinucleated cells were visible by 14 days. After 28 days (Fig. 1A), the granulations looked more mature, their number and volume decreased, and the response of macrophages and giant cells to the foreign material was less pronounced. At the site of the membrane implantation in the thigh muscle, a large number of free lumps of foreign light-refracting material were found, which were surrounded by epithelioid cells, a large number of giant cells of foreign bodies, granulation tissue with well-formed vessels, moderate infiltration of lympho-macrophage elements, and weak infiltration of segmented nuclei. In the cytoplasm of macrophages and multinucleated cells, granules of a foreign light-refracting substance were detected. Edema and plethora remained in the muscle tissue of the thigh, fibroblasts were accumulated between the fibers, and foci of proliferation of nuclei in the muscle fibers were observed. Similar responses persisted in animals on day 42; however, part of the implanted membrane was absent and a slit-shaped bed was detected in its place, which contained fragments of the membrane.
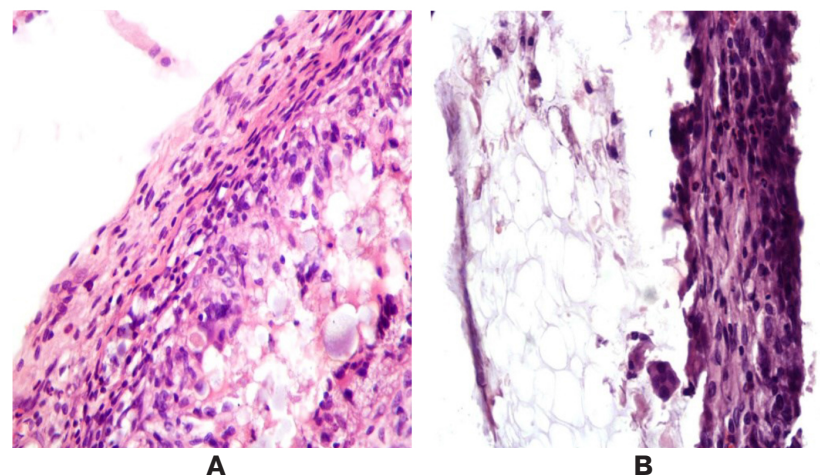

Fig. 1. Histological imaging depicting membrane resorption. The term of withdrawal from the experiment is 28 days:

A - Histological image of the biodegradation of the plate based on the PVSF composition. Hematoxylin-eosin stain,

x200 magnification; B - Insulated plate on the basis of a classic membrane based on PVA. The term for removing

their experiment is 28 days. Hematoxylin-eosin stain, x200 magnification

In the control group with free PVA membranes (Subgroup A b) on day 14, the muscle tissue contained a twisted translucent membrane that was surrounded by a granulation shaft with a pronounced macrophage/giant cell reaction to foreign material. At 28 days, a fibrous capsule with no signs of inflammation and an insignificant macrophage/giant cell response were observed (Fig. 1B). On day 42, a translucent cellular structure remained surrounded by a mature fibrous capsule.

Thus, on day 14, in all animals of Subgroup $A$ a, the PVAF membrane was partially absent; in the control Subgroup A b, the PVA membrane was unchanged. The state of the membrane in the control subgroup remained unchanged throughout the observation period. In experimental Subgroup $\mathrm{A}$ a, on day 28, traces of the membrane were detected in more than half of the animals; on day 42, this phenomenon was observed in all mice. Despite the less intense metabolic processes in Subgroup B a than those in Subgroup A a, PVA membrane fragments with signs of active vascularization were found in the area of the bone defect on day 90 (Fig. 2A). Fibrous tissue was not detected around the PVA membrane fragments. 
The lymphocytic macrophage reaction around the membrane microfragments was weak or absent. Moreover, the structure of the residual membrane fragments in the microphotographs was cellular and friable with exfoliating droplet-like patches in the

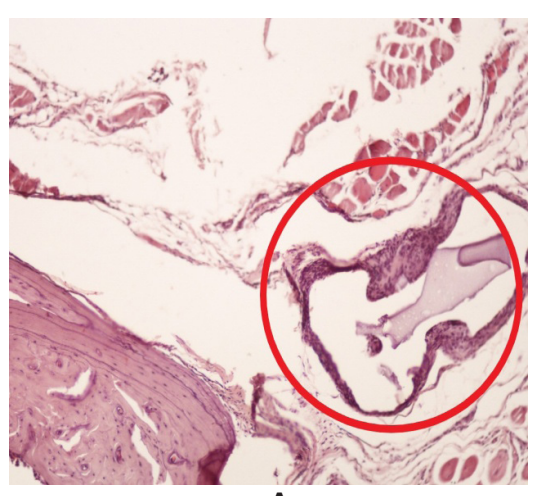

A

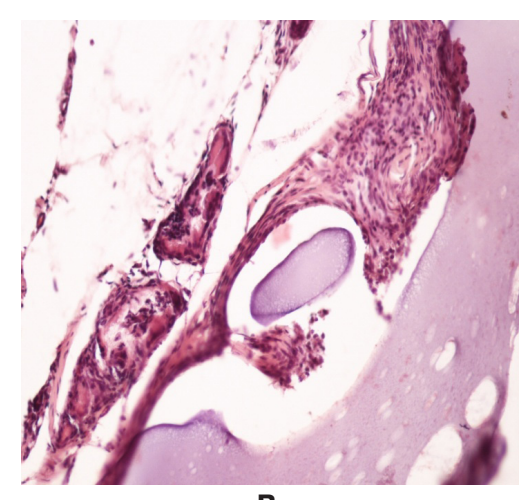

B natural interstitial fluid (Fig. 2B). As on day 42, the PVAbased membrane at 90 days was surrounded by mature fibrous tissue. The structure of the PVA membrane did not change visually or in micropreparations between day 42 and 90 (Fig. 2B).

Fig. 2. Histological imaging of resorbed membrane. The term of withdrawal from the experiment is 90 days: A - Fragmentation of a membrane for directed regeneration based on a PVAF composition. Mild lymphocytic macrophage infiltration is evident. Hematoxylin-eosin stain, x200 magnification; B - Bioresorption of a membrane fragment for directed regeneration based on a PVAF composition. Hematoxylin-eosin stain, x400 magnification; C - Membrane based on a PVA composition. The formation of fibrous tissue is evident. There are no signs of an inflammatory reaction. Hematoxylin-eosin stain, x200 magnification

A statistical comparison based on the Chi-square Pearson criterion of the biocompatibilities of the PVAF and PVA membranes was carried out on a three-point scale for each period after which animals were removed from the experiment. The suitability of using the Chi-square criterion for contingency tables was verified using Simonov - Tsai diagnostics. The diagnostic value $S$ of 0.13 , which is less than 0.25 , indicated the validity of the Chi-square approximation. The null hypothesis is the absence of differences in the frequencies of the occurrence of different states of the membranes in the experimental and control groups. The result of the calculation of the Chi-square criterion (in each period, Chi-square criterion $=42.0, \mathrm{df}=2$, and P-value $=0.000$ ) was highly statistically significant, which showed that the data obtained did not agree with the null hypothesis. Thus, there were highly statistically significant $(p<0.001)$ differences in the biocompatibilities of the studied membranes. The PVAF membrane was bioresorbable to a greater extent than the control PVA membrane.

Conclusions. Membranes based on polyvinyl alcohols with varying degrees of hydrolysis and $\mathrm{C}_{60}$ underwent effective bioresorption, which should aid the directed regeneration of bone tissue. Membrane bioresorption occurred naturally in the period from 14 to 90 days after implantation. In contrast, the control membrane composed of polyvinyl alcohols of varying degrees of hydrolysis without $\mathrm{C}_{60}$ was encapsulated without bioresorption. The resorbable membrane did not adversely affect the surrounding tissues and is attractive for use in clinical practice.

\section{Disclosures:}

The authors declare no conflict of interest.

Acknowledgment:

We thank Natasha Lundin, PhD, from Edanz Group (www.edanzediting.com/ac) for editing a draft of this manuscript.

\section{References}

1. Ivanov A. S. Osnovy dentalnoy implantacii. SPb.: SpeczLit; 2013.

2. Usikov L. V., Iordanishvili A. K., Balin D. V., Shengeliya E. V. Morfologicheskie i klinicheskie aspekty reparativnoy regeneracii kostnoj tkani chelyustey. SPb.; 2014

3. Lee S.-W., Kim S.-G. Membranes for the guided bone regeneration. Maxillofacial Plastic and Reconstructive Surgery. 2014;36(6):239-246. https://doi.org/10.14402/jkamprs.2014.36.6.239

4. Bottino M. C., Thomas V. Membranes for periodontal regeneration - A materials perspective. Front. Oral Biol. 2015;17:90-100. https://doi.org/10.1159/000381699

5. Ruiz-Rubio L., Pérez-Álvarez L., Vilas-Vilela J. L. Biodegradable shape-memory polymers. Adv. Struct. Mater. 2020:115:219-236.

https://doi.org/10.1007/978-981-13-8574-2_10
6. Milosevic M. Polymerization mechanics of dental composites-advantages and disadvantages. Proc. Eng. 2016;149:313-320.

https://doi.org/10.1016/j.proeng.2016.06.672

7. Franskevych D., Palyvoda K., Petukhov D., Prylutska S., Grynyuk I. [et al.] Fullerene $\mathrm{C}_{60}$ penetration into leukemic cells and its photoinduced cytotoxic effects. Nanoscale Res. Lett. 2017;12(1): art. № 40.

https://doi.org/10.1186/s11671-016-1819-5

8. Grebinyk A., Grebinyk S., Prylutska S., Ritter U., Matyshevska O. [et al.] $\mathrm{C}_{60}$ fullerene accumulation in human leukemic cells and perspectives of LED-mediated photodynamic therapy. Free Radical Biol. Med. 2018:124:319327. https://doi.org/10.1016/j.freeradbiomed.2018.06.022

\section{About authors:}

Grebnev Gennadii Aleksandrovich, Honored Doctor of the Russian Federation, MD, PhD, Professor, Head of the Department of oral and maxillofacial surgery; tel.: +78124957203; e-mail: grebnev06@rambler.ru 
Kabankov Andrey Vasilievich, Dentist surgeon; tel.: +78127407581; e-mail: Viandr2007@yandex.ru

Garunov Musa Magomedovich, Senior Laboratory Assistant, Department of dentistry; tel.: +7921886312; e-mail: leondent@mail.ru Rumakin Vasiliy Petrovich, MD, Associate Professor of Departament of pathological anatomy; tel.: +78126709592; e-mail: vprumakin@rniito.ru

Borodulina Irina Ivanovna, MD, PhD, Professor, Department of oral and maxillofacial surgery; tel.: +78124957203; e-mail: borodulina59@mail.ru

ISSN - 2073-8137

\title{
COMPARISON OF THE EFFECTIVENESS OF VARIOUS SULPHUR-CONTAINING HEPATOPROTECTORS AGAINST CHRONIC ALCOHOLIZATION
}

\author{
Bykov I. M., Berberidy H. P., Popov K. A., Ermakova G. A., \\ Tsymbalyuk I. Yu., Esaulenko E. E., Denisova Ya. E., Azimov E. A. \\ Kuban State Medical University, Krasnodar, Russian Federation

\section{СРАВНЕНИЕ ЭФФЕКТИВНОСТИ РАЗАИЧНЫХ СЕРОСОАЕРЖАЩИХ ГЕПАТОПРОТЕКТОРОВ В КОРРЕКЦИИ ХРОНИЧЕСКОЙ ААКОГОАЬНОЙ ИНТОКСИКАЦИИ В ЭКСПЕРИМЕНТЕ}

\author{
И. М. Быков, Х. П. БербериАи, К. А. Попов, Г. А. Ермакова, \\ И. Ю. Цымбалюк, Е. Е. Есауленко, Я. Е. Аенисова, Э. А. Азимов
}

\section{Кубанский госУАарственный МеАицинский Университет, КрасноАар, Российская ФеАерация}

\begin{abstract}
Studies on the treatment of intoxication caused by prolonged use of alcohol are necessary. Herein, the influence of ademetionine, methionine and lipoic acid under various administration schemes on the course of chronic alcoholization was compared. The study was performed on 125 white nonlinear male rats (initial body mass: 220-250 g) divided into seven groups. Groups 2-7 underwent alcoholization for two months. The rats of groups 3-7 were administered ademetionine, methionine or lipoic acid. We determined herein that ademetionine injections had the most significant hepatoprotective and antioxidant effects, and they maintained the mitochondria in an adequate functional state. Methionine administration showed no cytoprotective effect, and it was characterized by mitochondrial dysfunction and a more significant increase in the activity of hepatic cytolysis markers. The lipoic acid injections had a significant antioxidant effect, but their cytoprotective effects were mild. On the basis of our findings, we concluded that the substances tested here mainly improved metabolic disorders induced by chronic alcoholization via maintenance of the detoxification and biosynthetic functions of the liver.
\end{abstract}

Keywords: alcoholization, oxidative stress, antioxidant system, methionine, lipoic acid, ademetionine

Проведено сравнительное исследование влияния адеметионина, метионина и разных схем введения липоевой кислоты на течение хронической алкогольной интоксикации. Исследование проведено на 125 белых нелинейных крысах-самцах с исходной массой 220-250 граммов, разделенных на 7 групп. Животные 2-7-й групп в течение 2 месяцев подвергались алкоголизации. Крысам 3-7-й групп с целью коррекции вводили адеметионин, метионин или липоевую кислоту. В результате проведенных исследований было установлено, что применение адеметионина оказывало наиболее выраженное гепатопротекторное и антиоксидантное действие, а также способствовало поддержанию адекватного функционального состояния митохондрий. Включение исследуемым животным метионина не оказывало цитопротекторного действия, а, напротив, характеризовалось еще более значительным увеличением активности маркеров цитолиза гепатоцитов в плазме крови и митохондриальной дисфункцией. Введение липоевой кислоты оказывало выраженное антиоксидантное действие, но цитопротекторный эффект был незначителен. Таким образом, ведущее значение для коррекции метаболических нарушений при хронической алкогольной интоксикации имела поддержка детоксикационной и биосинтетической функции печени.

Ключевые слова: алкогольная интоксикация, окислительный стресс, антиоксидантная система, метионин, липоевая кислота, адеметионин

For citation: Bykov I. M., Berberidi H. P., Popov K. A., Ermakova G. A., Tsymbalyuk I. Yu., Esaulenko E. E., Denisova Ya. E., Azimov E. A. COMPARISON OF THE EFFECTIVENESS OF VARIOUS SULPHUR-CONTAINING HEPATOPROTECTORS AGAINST CHRONIC ALCOHOLIZATION. Medical News of North Caucasus. 2019;14(3):523-527.

DOI - https://doi.org/10.14300/mnnc.2019.14129 